\title{
Relational Goods and Resolving the Paradox of Political Participation
}

\author{
Los bienes relacionales y la resolución de la paradoja \\ de la participación política
}

\author{
CAROLE J. UHLANER
}

UNIVERSITY OF CALIFORNIA, IRVINE

Article received: 09 August 2013

Review requested: 18 September 2013

Article accepted: 09 October 2013

\begin{abstract}
Relational goods provide a theoretical explanation for the puzzling fact that rational individuals engage in collective action, including political participation. Relational goods facilitate provision of public goods, although they are not public goods themselves. A relational good only exists when non-anonymous others share the good, the «identity» characteristic, but these might not be specific individuals in direct contact. «Indirect» relational goods, shared with persons of a certain type, such as a certain social identity, can also increase participation. It remains theoretically problematic how well-defined the «other» must be for a relational good to exist. The indirect relational goods provide key opportunities for elites to mobilize participation. Support for the role of relational goods in collective action comes from substantial empirical work (using survey data and field experiments) examining the roles of publicity, group identification, and mobilization in increasing political participation.
\end{abstract}

Keywords: Relational goods, social identity, mobilization, political participation, collective action.

Resumen

Los bienes relacionales ofrecen un marco teórico capaz de explicar el desconcertante hecho de por qué los individuos racionales participan en la acción colectiva, en la que se incluye la participación política. Los bienes relacionales facilitan la provisión de bienes públicos, aunque estos no sean en sí mismos bienes públicos. Un bien relacional sólo existe cuando se comparte un bien con otros sujetos no-anónimos -la característica de «identidad»pero estos podrían no ser individuos específicos en contacto directo. Bienes relacionales «indirectos», compartidos por personas de un determinado tipo, como puede ser una cierta identidad social, también pueden aumentar la participación. Sigue siendo una problemática teórica el saber cómo definir bien la figura del «otro» para que pueda existir un bien relacional. Los bienes relacionales indirectos proporcionan oportunidades básicas para que las elites puedan lograr movilizar la participación. El apoyo del papel que desempeñan los bienes relacionales en la acción colectiva viene ratificado por un sustancial trabajo empírico (basado 
en encuestas y en trabajos de campo) que examina los papeles de la publicidad, de la identidad de grupo y de la movilización de una creciente participación política.

Palabras clave: bienes relacionales, identidad social, movilización, participación política, acción colectiva

The fact that people engage in collective action is one of the more puzzling aspects of political behavior. If one assumes that people rationally weigh benefits and costs, then analysis concludes that most people will choose inaction. Since we observe many more members of the public participate than predicted, there is a contradiction, often thought of as a paradox. We can, at least partially, solve the puzzle by acknowledging that people value relational goods. These are goods which cannot be acquired by a person in isolation, but which only exist by mutual agreement as part of a relationship with specific others; moreover, sharing the good provides part of the value. Friendship is a prime example of a relational good.Various pieces of empirical evidence support the view that relational goods account for much political participation. Moreover, understanding relational goods helps to clarify how and why group identity plays its substantial role in political behavior.

Political participation is a form of collective action. The typical outcome is a public good (such as a government policy or an election outcome). At the same time, each individual's actions (voting, demonstrating, giving money to a campaign, contacting an official) has a small to negligible probability of changing that outcome, even if collectively the actions are powerful. Why, then, would people take these actions? Many of the answers to this quandary, both those within a rational actor paradigm and those proceeding from sociology or psychology, end up assuming that people do so for reasons beyond making an actual difference in achieving the collective outcome (see Bardsley 2005; Blais 2000; Aldrich 1993). They may act from a sense of duty, or from the sheer enjoyment of the action, or out of habit. Empirical research has established some factors associated with higher participation. Notably, elites increase participation via a process labeled recruitment or mobilization, but exactly what this means for the individual citizen is under-specified. It is very difficult to argue plausibly that the public good of the outcome provides the reason for action. And the various private goods proposed as reasons end up generating ad hoc explanations.

Once we acknowledge that people value relational goods, however, the explanations become coherent. The increased participation associated with recruitment, with feelings of obligation, and with identification with some 
group all indicate an important role for relational goods. As discussed below, in the contemporary United States, ethnicity and race serve as especially politically salient group identities ${ }^{1}$. Relational goods provide a theoretical grounding for the way these factors operate to increase participation.

Note that relational goods will not always increase the probability of political participation or, more generally, collective action. If the people with whom one relates instead consider action to have negative value or affirmatively value inaction, then the effect will be the opposite; relational goods will reduce political participation. Thus, (some) people must evaluate action nonnegatively for relational goods to increase participation. Second, for participation to increase, a relational good must be tied to the participatory action, either inherently (received in the course of taking the action) or consequently (increased as a result of taking the action).

Many relational goods of course have no direct connection with political participation or collective action; two people can share friendship without any reference to politics. Someone can value being included as having a certain national homeland without political implications. But if one of the friends becomes an enthusiastic campaigner for an election candidate, or if others from that homeland equate support for language policies with the right to consider oneself a «real» member, then action maintains or strengthens the relational good. Relational goods are not themselves a public good, as Bruni (2008; also Bruni and Zamagni, 2007) points out. But the utility derived from them helps to account for why people are willing to contribute to obtaining a public good.

A number of authors simultaneously developed the idea of relational goods, ${ }^{2}$ each with somewhat different definitions and emphases, and later accounts offer sometimes variant interpretations of the ideas. Bruni and Zamagni synthesize these approaches to offer a list of «basic characteristics of a relational good» (Bruni and Zamagni, 2007, pp. 242-244; also Bruni, 2008, 132-133). ${ }^{3}$ In what follows, I use that list to review and elaborate upon my conception of relational goods, with particular attention to the aspects of the theory that are important for understanding political participation. These include «identity» and the distinction between «direct» and «indirect» rela-

1 Relevant identities will vary in other places and at other times depending upon the political cleavages and political culture.

2 Bruni and Zamagni (2007 p. 239) credit the concept to myself (Uhlaner 1989a), Nussbaum (1986), Gui (1987), and Donati (1986). See also Gui (2000, 2005) and Donati (2011) for English language presentations.

3 These are «identity», «reciprocity», «simultaneity», «motivations», «emerging fact», and "goods» (versus «merchandise»). In my view, and when thinking of collective action, some of these characteristics are more central than others for characterizing relational goods. 
tional goods. I then present some of the accumulating empirical evidence for the importance of relational goods in understanding political participation, drawing in particular upon work on ethnic and racial politics. I also discuss how to improve research by more explicitly incorporating relational goods into theory.

\section{UHLANER'S CONCEPTION OF RELATIONAL GOODS}

Consistent with other scholars, I conceive of relational goods as something apart from either private or public goods. «Relational goods can only be enjoyed if shared with some others» and where «a person's utility increases both as his or her own consumption increases and as the consumption of some specific other person or member of a defined set of people increases» (Uhlaner, 1989a: 254).This concept corresponds to Bruni and Zamagni's «reciprocity» characteristic (2007: 243). With a public good, in contrast, a person would be just as happy to consume it all on her own; I enjoy clean air whether or not you are breathing it, too. I can even enjoy the public good of seeing a beautiful sunset without you; the additional enjoyment I get from sharing the view with someone else is a relational good. Second, relational goods can only be 'possessed' by mutual agreement; they exist only after a person and non-arbitrary others take appropriate joint actions (Uhlaner, 1989a: 254). This corresponds to Bruni and Zamagni's «simultaneity» term (2007: 243). Not only does a relational good appear simultaneously in the utility functions of two or more people, but its presence in both is what increases the enjoyment (utility) of each person. For my theoretical purposes, the "motivations," «emerging fact,» and "goods» characteristics (Bruni and Zamagni 2007: 243-244) blend together. A relational good requires the relationship (as the reciprocity and simultaneity terms also suggest) but moreover has meaning and utility in itself, not solely as a means towards another end. In that regard, and somewhat contradictory to Bruni and Zamagni's characterization of my view, I do see «friendship» as a relational good: people may repeatedly interact in various ways without being friends, but the relationship of «friendship» is a relational good, requiring mutual recognition. Moreover, somewhat counter to Bruni and Zamagni's «motivation» term, but consistent with Gui (2005), I agree that while a relational good must be valued for itself and must be pursued for its own sake, nonetheless it can additionally be useful for obtaining something else without forfeiting definition as a relational good.A friend may in future find that her relationship eases obtaining a job 
interview; as long as the friendship was not pursued for that end, it remains a relational good.

The remaining characteristic on the Bruni and Zamagni list, «identity,» (2007: 242-243) is both fundamental and problematic. As noted just above, for me a relational good must involve a relationship between someone and some specific other or others, not just an anonymous relationship. For many relational goods, such as friendship or love, as ordinarily understood, the interaction must be with a specific person. For others, such as Nussbaum's (1986) «civic commitment» or Sugden's $(2002,2005)$ «fellow-feeling,» the relationship may be with any or many other individuals including ones known only as a «type» of person rather than as a specific named person. In the sunset example from above, or while sitting in a theater, I may even derive a relational good, a pleasure, from sharing the experience with strangers. I do not know their names nor expect to see them again, but I do recognize them as somehow like me (very much in the sense of Sugden's fellow-feeling). While complete anonymity disqualifies a good from being relational (for example, the value of «money» depends upon mutual agreement, but the value is independent of whoever provides it), a very short step away from anonymity may be sufficient to create the conditions for a relational good. Moreover, an external objective observer cannot ascertain how much non-anonymity is sufficient to create a relational good; it inheres in the subjective experience of each actor. These more impersonal relational goods, which are important for understanding political participation, raise interesting questions about subjectivity and objectivity and about how much «identity» is needed to make a "good» relational. "Identity» thus is a slippery yet crucial component of the characterization of relational goods.

Admittedly, some contrarian persons put high value on being unlike others, and hermits value solitude; the effects of relational goods on actions would be different for them than for most people. Therefore, for simplicity, but also realistically, the following discussion assumes most people wish to be like others and to be connected to others. Note that even for someone who prefers to be «unlike,» the relational goods still differ from ordinary private and public goods. However, much of this literature, including what follows, focuses upon those who are sociable rather than the hermetic exceptions.

My earlier work (Uhlaner 1989a, prefigured in Uhlaner 1986) developed the idea of two types of relational goods labeled «direct» and «indirect,» according to whether the contact among those interacting is in person (direct) or at a distance (indirect). Donati's primary and secondary relational goods (2011: 158) capture a similar distinction. These types roughly correspond 
to interaction with a primary group versus with a secondary group, but my concept is a continuum rather than a dichotomy, as there are degrees of indirectness.

In the direct case, individuals interact face-to-face (these days, possibly virtually instead of literally), but in any event they know each other personally. The relational good arises from interaction with a specific known other individual, and thus mutual knowledge and mutual observation are both likely. Here there is clearly no anonymity. Moreover subjectivity and objectivity will coincide; both or all parties will agree that they are in a relationship with each other. ${ }^{4}$ Direct relational goods can increase political participation, as when one life-partner expects the other to vote. In my formal development (Uhlaner 1989a) I modeled the relational good as each party valuing being the same as the other, as valuing the other taking the same action, or inaction, as oneself. Whether increased participation follows depends upon the relative values of the non-relational benefits (the other instrumental and consumption benefits from participation, minus the costs) as compared with the relational good benefit (Uhlaner, 1989a: 263). There is some role for elite mobilization, by enhancing coordination and side payments or by manipulating perceptions of the other participants' values. However, since direct relational goods by definition involve individuals who are in direct contact, the room for manipulation is constrained.

Valuing acting the «same» is a relational good because it requires simultaneous, reciprocal action with a specifically identified other person. One cannot act the same as someone else in isolation, or absent shared action. Admittedly, in this conception valuing being the same might be interpreted as instrumental to the goal of maintaining the relationship, such as friendship, and thus the relational good seen as instrumental and not inherent in the relationship. Choosing to act the same thus maintains the relationship and the relational good which arises from it.

I now think that my earlier discussion (1989a) neglected another aspect of relational goods. People who are in a relationship find value in being together and, in the case of participation, taking similar actions. My prior development omitted the relational good that arises from the action itself, the utility derived from doing something with a valued other person. Consider a person who is helping a political candidate's campaign by making phone calls to potential supporters and who asks her friend to do the same. If they each get a list of numbers to contact and make the calls in isolation in their separate homes, they derive some relational good benefit from sharing their

4 This assertion may not hold for persons detached from reality; we assume basic sanity. 
work in support of the candidate. But if they sit together in the same room making the calls, they have the added relational good arising from the companionable time spent together.

More generally, my previous development focused too much upon people participating in part to maintain a friendship or other relationships, thereby making the action instrumental towards maintaining a connection that provides relational goods. What I failed to include, and now see as very important, is that the act of participation itself provides relational goods, or can do so. My spouse may want me to vote and by doing so I enhance our domestic tranquility, but I also derive some real pleasures from visiting with my neighbors while waiting in line at the polling place. Similarly, relational goods may be obtained by people making phone calls in the campaign headquarters where they have camaraderie with fellow campaigners, or by people attending a community meeting and socializing.

These examples move us farther towards the «indirect» good end of the spectrum. The indirect goods are both more useful for understanding political participation and more problematic to define. «A person can derive relational benefits from a group even in the absence of face-to-face contact. For such benefits to be available, a person must think of him or herself as part of a group.... Although in the case of indirect contact, the outcome to an individual, and hence the value of these relational goods, depends upon the actions of both self and others, those others need not be explicitly aware of one's decision-making [or, I would now say, actions]» (Uhlaner, 1989a: 256). Perhaps the paradigmatic example of such goods is social identity, the feeling of belonging to a particular group in society and being accepted by the other members of that group.

The conceptual problem arises from the notion of "group.» Groups vary along a continuum in terms of how identifiable members are to each other and the nature of their interactions and thus whether the relational goods are direct or indirect.At one end, specific individuals know each other and interact directly. In groups farther along the spectrum, members interact with some other members whose actions they can observe, but they know many other members only by type and have only indirect contact. At the far end of the continuum membership depends only upon a subjective sense selfenforced by adherence to perceived norms. Anonymity lies just a short step away, yet pure anonymity would take us outside the realm of relational goods. Even if at the far end of the indirect goods the specific others are not exactly identifiable, neither are they entirely anonymous. I may not know the other people by name, but I do know them as being supporters of candidate $\mathrm{X}$, or residents of neighborhood $\mathrm{Y}$, or people who share my ancestral homeland, 
and feel a connection to them on that basis that I value maintaining. Solidary goods, or sociability, fall into this middle ground, where a person feels connected to some specified subset of people even without really knowing who they are.

The direct relational goods are in many ways easier to understand. It seems that (almost) everyone values friendship, and there are probably sound evolutionary reasons for this preference. The indirect relational goods are likely less universal and in any case more variable. While there is a general propensity towards "groupness,» as shown by the work of Tajfel (1982; Tajfel et al., $1971)$ and Turner $(1975 ; 1982)$ and others working on social identity, individuals differ. Individuals also differ in how broad a definition they accept for their group, with «all of humanity» or «all creation» an extreme claimed by some, but credibly only by very few. Relational goods closer to the anonymity pole depend more upon the person's subjective sense of self-identification; the farther from anonymity, the more it depends upon objective inclusion by others.

A further conceptual distinction - between consumption and instrumental indirect relational goods ${ }^{5}$ - clarifies the role of relational goods in political participation. The distinction arises especially in understanding elite mobilization and the role of group identity.The consumption indirect relational goods are those whose receipt depends only upon performing some action. For instance, participants in a protest demonstration against the killing of whales derive a consumption relational good from an enhanced sense of self as an environmentalist (or perhaps more specifically as a supporter of Greenpeace), along with whatever direct relational goods, including enjoyment of the event, they receive from interacting with other people at the protest. These direct and consumption indirect relational goods depend only upon having been a participant, independent of the effect. But additionally the protest may have some policy consequence, such as stimulating tighter regulation of whaling or increasing the salience of the issue.That part is available to all members, whether or not they participated, and thus faces the usual problems of public goods. The additional investment relational good arises «if action by one's group bolsters the group's political identity» (Uhlaner 1989a: 257) thereby increasing its power and influence and, crucially, the person only gets his or her share of that enhanced identity by having taken

5 Benedetto Gui distinguishes between consumption relational goods and relational goods that take the form of capital where the latter «is first accumulated and then put to use in further interactions» to produce further relational goods (Gui 2005:. 42; also Gui 2000). This distinction is related to mine between consumption and investment relational goods, but not identical, given his broader and my narrower focus. 
part in the action, thereby strengthening the claim to membership in the group. These relational goods, like the others, depend upon the actions both of the self and of other people. Slogans used by the Obama campaign in 2008 played on feelings like these, asking prospective voters (or abstainers) to «be part of the change.» In sum, in these cases, the consumption indirect relational goods involve enhancing one's own sense of identity, while the investment indirect relational goods also enhance the value of that identity.

The above examples presume that the value of relational goods will increase the benefit of collective activity, but this presumption rests upon political action being valued. For some groups, identity includes the avoidance of politics, and in those cases the relational goods will weigh against political action and decrease activity. Various religious groups have at different times and places made a virtue of avoiding the secular and especially of avoiding secular authority. In those cases, consideration of relational goods may account for lack of political action in circumstances where otherwise it might be expected. However, we have seen groups shift attitudes from avoidance of politics to embracing it; the Christian New Right in the United States provides one example.

Indirect relational goods provide multiple opportunities for elite actions to increase participation. ${ }^{6} \mathrm{~A}$ person deciding whether or not to act weighs both individual benefits and costs and relational goods in his or her utility function, weighting according to personal preference. For clarity of exposition, assume the person prefers to be accepted by others and that acting similarly increases acceptance. The relational goods received after acting or not - will depend upon what the relevant others do. Thus the person's decision requires predicting the actions of others. That prediction rests upon assessing the individual benefits and costs of action for others and also the value the others place on similarity, the relational good. In the indirect case, third parties - such as elites with an interest in mobilization - can easily affect these estimates, as people will have little first-hand information about each other. Elite mobilization, then, may happen by persuading people that others whose relationship they value are likely to act (so similarity requires one's own action). Elites may also mobilize by persuading someone that others are unlikely to be dissuaded by one's own reluctance to act (that they value similarity less). Instrumental indirect relational goods provide benefits beyond similarity and acceptance. The benefits of action increase if the potential participant believes enough members will participate to enhance the

6 The summaries below are formally developed in Uhlaner 1989a using game theory and decision theory analyses. 
group's political presence, and the benefits increase further the greater the value of that political presence. Thus, an elite-conveyed message that «everyone» is acting would increase activity, counter to what one would expect of free riders. The key point is that leaders can manipulate and enhance the value of relational goods.

When political action is connected to receiving relational goods, the following additional conditions are likely to lead to political participation by members of the relevant group. Where members of the group interact more with each other there will be more activity, as there is more opportunity for direct relational goods to exist and to reinforce indirect relational goods. The value of the relational good will rise, thereby increasing activity, if members strongly identify with the group, and rise more for those who care most about the identity. Finally, the connection of the relational good to political activity will be more effective and thus lead to more action if the members of the group are more homogeneous in their political preferences, such as for a particular political policy or leader. ${ }^{7}$ The available empirical evidence provides suggestive, albeit not definitive, support for these propositions.

Of course not all political participation produces social good, despite the implicit positive evaluation in much of the contemporary political science literature. Collective action of all types can be harmful. History presents many cases of people working together to produce social ills (gangs, Blackshirts, ethnic «cleansers»). Elite mobilization often plays an important role in those cases, and all the considerations above apply. Whether the behavior is for good or ill, the same paradox of collective action applies and relational goods provide an answer in either case.

\section{EMPIRICAL SUPPORT: MOBILIZATION, FIELD EXPERIMENTS, SOCIAL MEDIA}

Over the last decades, accumulating empirical work supports the role of relational goods in producing political participation. This work rarely explicitly references relational goods, but the interpretation is often straightforward. One important strand of this work uses sample surveys and shows the importance of recruitment. Another strand using field experiments shows the effectiveness of recruitment and of scrutinizing activity. Other support comes from work on the political behavior of ethnic and racial minorities.

7 When preferences are heterogeneous, group members are less likely to feel that group identity depends upon acting in a particular way. 
Two studies explicitly test relational goods. One (Leighley 2001) uses indicators rather distant from the concept and finds mixed results, while another (Le 2013) which uses better indicators of relational goods finds a substantial effect on political activity.

Arguably the most fully realized account of political participation comes from the work of Sidney Verba, Henry Brady and Kay Schlozman (1995). They define political participation quite broadly, including both electoral and nonelectoral activities and protest. Their Civic Voluntarism Model holds that political participation results from an individual's resources, engagement, and recruitment. Each of these factors increases participation, even controlling for each of the others. The resources include education, income, and adult civic skills (many of which are acquired within a group). Engagement includes psychological factors associated with concern about politics, such as general political interest, specific interest in an issue, party affiliation, feeling efficacious, and believing the norm that political activity is important. Note that in their work the norm is quite general, and there is no development as to its source or specificity. Recruitment refers to being asked to participate and is the component most germane to relational goods. They find that any level of resources and engagement, participation increases when someone is asked to participate. The increase is especially high when the request comes from someone known to the target (p.157), but the increase is also observed when the request comes from a religious figure, the workplace, or a leader of an organization to which the person belongs (pp. 389-390). Their work does not go further to explore the content of the request or why requests increase activity.

Relational goods suggest an explanation for why recruitment works to increase activity. The fact that recruitment is more effective when the relationship is closer suggests that the pursuit of relational goods factors into the acquiescence to act. If someone requests that I take an action, their preference is clear, as is my expectation that they will be pleased if I agree. I thus expect agreement to yield direct relational goods. Requests in the context of a workplace, place of worship, or organization will increase the value of the relational good and hence activity to the extent that the person values being part of that group.

Recruitment is not perfect; many people say no. People weigh the relational good with their other, non-relational benefits and costs from action. Moreover, the measures of recruitment in most studies, including Verba et al. (1995), are not precise enough to distinguish between the person who values being part of a particular group and the one who is indifferent or alienated. In a society where there is free association, it is reasonable to assume 
that there are more of the former than the latter. Hence overall recruitment will add positive benefits from relational goods to the plus side of the decision, and we get the observed association between being asked and acting.

Substantial support for the role of relational goods also comes from a growing body of field experiments studying voter mobilization, especially in the United States (see Green, McGrath, and Aronow 2013 for a review). While these authors do not explicitly discuss relational goods, the results strongly suggest their importance in producing activity. In these studies, researchers contact randomly selected potential voters with different messages and delivery mechanisms before an election. After the election, the researchers use official records to verify who voted. With that information they assess the effectiveness of the different contacts relative to the uncontacted control group. ${ }^{8}$

The types of contact vary in the amount of personal interaction they involve, and their effectiveness increases as there is more (Gerber and Green 2000; Green and Gerber 2008; Green, McGrath, and Aronow, 2013). The most effective method to increase turnout is door-to-door canvassing, where a campaign worker shows up in person to talk to the potential voter. Next in effectiveness come phone calls from committed volunteers. Much less effective are materials sent in the mail with a general exhortation (but see below) or phone calls from paid workers. Anonymous email blasts do nothing at all. Even the most effective form, the canvassing, does not produce many votes per contact, but it does far better than the impersonal forms. When a real person makes a real request, a relational good is much more likely to be produced then when information is received from an anonymous source. The telephone contacting is more effective when done by someone from the same political party as the contacted person; not only does that make sense in simple strategic terms, but such a contact is also more likely to evoke indirect relational goods, a sense of the group.

Subsequent field experiments investigating «social pressure,» «shame,» and «pride» even more clearly suggest the role of relational goods. These experiments manipulate the information people have about the past and future behavior of themselves and others and their beliefs about who will be told about their own future behavior. Overall, the results show higher turnout when a person thinks someone is watching whether or not they voted, and even more so when they think the information will be told to members of

8 About half of eligible individuals vote in U.S. presidential elections, and fewer in congressional, state, and local elections, so there is substantial variation to explain, unlike many other polities. At the same time, there is widespread normative agreement in the U.S. that voting is a good thing and a citizen's duty. 
their household or to their neighbors. People are more likely to vote when they believe someone close to them will have information on their fulfillment of the norm.

For example, Gerber, Green and Larimer (2008) ran an experiment in a Michigan 2006 election in which one group of people were provided a general normative exhortation to vote, a second group was just told that researchers were watching (but would not contact them again), a third group was provided their household voting history and told it would be updated after the election, and a fourth group was provided the same information and also for their neighbors' households (ten households in the authors' example). The four conditions increased turnout over the control group by, respectively, 1.8, 2.5, 4.9, and 8.1 percentage points. The first two are basically consistent with past results for the effect of mailed messages, just somewhat on the high side. The last two are a dramatic increase; when neighbors are told about neighbors, and informed that their own activity will be reported, the 8 point increase is equivalent to the turnout increase achieved by campaigners appearing in person on the doorstep. In the context of a widespread U.S. norm that voting is good, and on the assumption that most people wish to be accepted by their residential neighbors, these results strongly suggest the importance of a relational good in increasing activity. The third condition is ambiguous, since the researchers focus on the prospective voter receiving reports about his or own activity, but in fact the reports cover all members of the household. There is thus both a personal and a direct relational good component.

Sinclair, McConnell, and Green (2012) eliminate that ambiguity by limiting the contact and report to one member of each treated household. They find effects for the contacted person comparable in size to those in the third condition above (about a 4.5 percentage point increase in turnout).The turnout of other household members went up but only by about 1.3 points; they were not threatened with the monitoring of their behavior. Neighbors were treated quite differently; unlike in the 2008 study, there were no lists of neighbor behavior. Instead the study examined whether there were spillover effects in the neighborhood and did not find them. This null result supports the relational good interpretation for the 8 point increase observed in the 2008 study; what mattered was the direct sharing of information about neighbors with each other, not simply separate treatment of individuals who happened to live nearby.

With a somewhat different design, Panagopolous (2010) reported another experiment where relational goods seem to have played a clear role in increasing turnout. Residents of two small towns in Iowa (populations 
3600 and 1150) were respectively told that the names of voters would be published in the local paper (pride) or that the names of non-voters would be similarly publicized (shame). Turnout increased by about five percent for those promised pride and 7 percent for those threatened with shame, large increases compared with past work on mailed contacts. These increases in response to the promise of publicity in a small community suggest that relational goods are being weighed.The relational goods explanation gains more support from the fact that Panagopolous observed essentially no change in turnout in a third town where residents were promised «pride.» This third town was an order of magnitude larger than the first two ${ }^{9}$ and moreover likely to have weaker norms supporting voting.

Other studies found increases in turnout by telling people their own behavior is being monitored, though the effects are smaller than when neighbors are involved. Gerber, Green and Larimer (2010) showed members of a household their past participation or abstention (with a promise to follow up) and found similar increases in turnout to those achieved in the household condition in the 2008 Gerber et al. study. Similarly, Panagopolous, Larimer, and Condon (2013) increased turnout when they reported past activity to individuals and promised future monitoring. "What seems to matter to voters is an indication that someone or some entity is monitoring their voter record, and the thought of such observation increases their chances of going to the polls,» (Panagopolous, Larimer, and Condon, 2013). In these cases with only a few points increase in turnout, the evocation of relational goods is possible but less clear than in the case with neighborhood publicity.

A Facebook experiment provides additional evidence that people will claim to vote and actually vote so as to be similar to those they «like.» The researchers provided three types of messages to all U.S. residents of voting age who accessed Facebook on Nov. 2, 2010 (the day of a national election for members of Congress). The «social» treatment group (with 61 million members) was «shown a statement at the top of their 'News Feed'. This message encouraged the user to vote, provided a link to find local polling places, showed a clickable button reading 'I Voted', showed a counter indicating how many other Facebook users had previously reported voting, and displayed up to six small randomly selected 'profile pictures' of the user's Facebook friends who had already clicked the I Voted button.» (Bond et al., 2012: 295). A second treatment group (about 600,000) were shown all the above except NOT the pictures of friends. A third group of about 600,000 served

9 Holland, Michigan, was the site, population 35,000. Not only is this substantially larger than the Iowa towns, lessening the chance of close personal ties among all residents, but also Iowans are noted for their political engagement, Michigan residents less so. 
as the control and received no message. After the election, the researchers validated turnout for a subset of their subjects. ${ }^{10}$ Persons who received the informational message were no more likely to vote than the controls, while those who were shown pictures of "friends» were significantly more likely to vote (and to claim to vote by clicking the «I Voted» button). The increase was only .39 of a percentage point, but with the huge sample size, this was still a highly significant increase. Friends, but only close ones, ${ }^{11}$ of those who received the social treatment also were more likely to vote and to claim to vote, again by a small but statistically significant amount.

The results reported above suggest the role of relational goods in overcoming the collective action dilemma of political participation, but none are definitive. Paying explicit attention to relational goods suggests how to construct better tests and better models. In particular, these studies do not take account of variations across individuals in their desire to be like others, and in some cases they apply a broad definition of the "other.» Thus, the relational component is at best inferred. For example, relational goods theory implies that recruitment measures in survey work should interact whether a person is asked with how much attachment the person feels towards the group doing the asking.

In some cases the test could be tightened even with existing data. For example, in the Gerber, Green, and Larimer (2008) study, no distinction was made among neighborhoods in terms of their voting rates. Some of the neighborhood clusters reported to the subjects may have relatively more abstainers than others, in which case the locally normative behavior might be to abstain. For those clusters, the relational good component would decrease turnout with publicity, muting or reversing the overall effect. Conversely, the increase in turnout would be stronger for subjects living in neighborhoods where the rate was higher. More obviously, the distinction between only one versus all members of a household receiving information is crucial from the perspective of relational goods, yet treated unclearly and inconsistently in the current studies (except in Sinclair et al. (2012). ${ }^{12}$ Data could be reanalyzed to take closer account of household effects.

10 They used records from 13 states accounting for $40 \%$ of U.S. registered voters. Using first name, last name, and birth date, they found about 6 million successful matches from which they derived their estimates of actual (as opposed to self-reported) voting and abstention rates.

11 Closeness was measured by frequency of Facebook interactions.

12 Gerber, Green and Larimer (2010) eliminated households with three or more persons registered to vote. They are unclear how they handled households where one person voted in a prior election and the other did not; it seems from their description they must have omitted those households from the experiment. The examples in Panagopolous, Larimer, and Condon (2013) suggest that individuals learned only about their own history, not that of other household members, in contrast to the other studies mentioned, but the article is not explicit on this point. 
Unfortunately, these data are not sufficient to address another key implication of relational goods, namely, that these effects should be far stronger in situations where people actually care about others. Some of the variations the researchers find across different sites may well result from differences in how much people care to be accepted by their neighbors. In that regard, the Facebook study does have the advantage of having a measure of voluntary interaction, which is a reasonable indicator of the desire to maintain a connection.

\section{EMPIRICAL SUPPORT: ETHNICITY, RACE, AND GENDER IDENTITY}

Other support for the role of relational goods comes from work on the connection between racial, ethnic, or gender identity and participation. In contemporary U.S. politics, these categories serve as some of the omnipresent types of identity, both personal and political. Ethnicity, race, and gender provide a basis for instrumental relational goods for people who desire acceptance in these groups and who wish to maintain a self-image as a member. Moreover, these groups' political role guarantees that there will be elites ${ }^{13}$ who try to provide messages designed to increase political activity by members. As noted much earlier in this essay, the relational goods operating in these instances are typically closer to the anonymity end of the spectrum, where people care about their relationship with others known simply for their shared characteristic.

The evidence in this literature for relational goods effects is widespread but mainly indirect. First, much research has examined the behavior of people who identify with a group and believe that group has a claim to political redress for inequitable treatment. Most studies find increased political participation by people who have «group consciousness» or who perceive «linked fate» (Verba and Nie, 1972; Miller et al. 1981; Shingles 1981; Uhlaner, Cain, and Kiewiet, 1989; Tate 1991; Dawson 1994; Dawson 2003; Stokes 2003; Sanchez 2006). McClain et al. (2009: 476) explain «group consciousness is in-group identification politicized by a set of ideological beliefs about one's group's social standing, as well as a view that collective action is the best means by which the group can improve its status and realize its interests.» Linked fate entails perceiving that one's own life is affected by treatment of the group as a whole. Hence, the boost which group consciousness and linked fate give to participation partially reflects pursuit of an indirect instrumental relational

13 These political entrepreneurs include unelected leaders. See Uhlaner 1989b. 
good. Some studies find little increase in activity with group consciousness, especially for non-African Americans (e.g. Leighley and Vedlitz 1999). Measurement discrepancies account for some of the differences across studies (McClain et al. 2009). More fundamentally, some types of groups may be better-suited than others to give rise to indirect relational goods. ${ }^{14}$

A second stream of U.S. research found that members of historically underrepresented groups (racial and ethnic minorities and women) participate more when they have representatives - or candidates running for office from their group.A person who is descriptively represented in this way sees a representative who is «like me» and thus has that identity primed for politics and also gains efficacy. Moreover, the candidate who shares race, gender or ethnicity has an incentive to mobilize on these grounds. Latino turnout increases when there are Latino candidates or the likelihood of Latino candidates, although the data are strongest for local elections (Barreto, Segura, and Woods, 2004; Barreto, Villareal, and Woods, 2005; Barreto, 2007; but Leighley 2001 finds no increase). Other studies find African American participation increases with local representation but not necessarily with representation in Congress (Bobo and Gilliam 1990; Leighley, 2001; Tate 2003; Gay 2001 has mixed results). Rocha,Tolbert, Bowen, and Clark (2010) find that the turnout of both Latinos and African Americans increases when they have more descriptive representatives in the state legislature.

There is some evidence that women candidates and officials increase female turnout and interest in politics (Burns, Schlozman, and Verba, 2001; Reingold and Harrell, 2010). Uhlaner, Scola, and Cooper (2013) found that descriptive representation in the state legislature increases turnout for white women and both African American men and African American women. Although these results are suggestive, they lack any subjective component, so the assumption that relational goods are at play is somewhat tenuous.

A stronger link can be made. I have argued (Uhlaner 1989a, 1989b, 2002) that individuals often connect to the larger political world via leaders who enhance a sense of duty and who can effectively recruit if recognized concerned for the citizen's interests. If relational goods increase participation, then those individuals who feel connected to a political leader will be more active. Those elites have both the means and the incentive to provide benefits for action or exact sanctions for inaction. A person who feels that there is a leader who will potentially defend his or her interests is more likely to respond to that leader's request for action than in the absence of that linkage. Moreover persons who feel represented by someone are more likely to be in

14 This point is pursued further in the conclusion. 
a relationship where that representative has a channel through which he or she can recruit them and whereby benefits and sanctions can be transmitted. The representation literature naturally focuses upon formal representation by persons elected to office, but the relevant elites also include representation by interest groups and other intermediate bodies.

Some data support these claims. The 1990 Latino National Political Survey (LNPS $)^{15}$ taps subjective representation by asking respondents, «Is there any group or organization that you think looks out for your concerns, even if you are not a member?» The majority of Latinos were served by non-Latino elected officials, but numerous intermediaries have attempted to organize Latinos along ethnic and national origin lines.About a quarter to a third of respondents (depending upon national origin and citizenship status) say they thought someone looked out for them. For each Latino national origin group, for both citizens and noncitizens, persons who feel represented are more likely than those who do not feel represented to participate in both electoral and nonelectoral activities (Uhlaner 2002). ${ }^{16}$ One finding is especially suggestive that the elite relationship is producing the increased activity via the enhancement of indirect relational goods. The most marginalized respondents, the noncitizen Mexican Americans, are the persons least likely to participate more when they perceive subjective representation. Thus, perhaps the process requires a minimum threshold of incorporation with a corresponding minimum sense of duty to act and perception of sanctions and incentives attached to political activity.

\section{EMPIRICAL WORK WHICH PAYS EXPLICIT ATTENTION TO RELATIONAL GOODS}

Two empirical studies of ethnic politics explicitly assess the role of relational goods. Leighley (1991) incorporates the concept of relational goods into her examination of the effects of political context on political participation, especially for Latinos and African Americans. Leighley uses a variety of both national U.S. and Texas data from the mid-1990s to test her models. She finds solid support that mobilization (or, interchangeably, recruitment)

15 The LNPs separately sampled Mexican American, Cuban American, Puerto Rican, and «other» adults across the U.S., including both citizens and noncitizens.

16 Subjective representation increases voting and registration among Mexican American and Puerto Rican citizens. The one exception to its effects occurs for Cuban American citizens; those who report subjective representation are a little less likely to register and to vote. Subjective representation increases participation in all five of the other measured activities for both citizens and noncitizens of all three national origin groups. 
increases participation. Her findings on relational goods are mixed. In part she argues there is strong support due to the increase in participation when there is recruitment, and especially recruitment by a known individual. In other tests, she construes the relational good argument to predict that there will be an increase in mobilization or in participation when the minority population is larger, and finds instead no or negative associations between group size and mobilization and participation. ${ }^{17}$ However, I would expect no particular relationship between the number of minority individuals in an area and some of the factors important for producing relational goods, such as the density of interactions, and at best a very weak association with other factors, such as the desire to be part of the group. The null results on the effects of group size thus seem to me to be testing group size, not relational goods. She does, however, find that individuals of all races are more likely to vote when they perceive their neighborhoods as more racially or ethnically homogeneous. ${ }^{18}$ That result is consistent with the effect of relational goods, albeit not strong support. Nonetheless, on the whole, Leighley concludes that her study supports the argument that relational goods increase political participation.

More pointed evidence comes from a recent study by Le (2013) of Vietnamese Americans in Orange County, California. She surveyed a more limited population, but the concepts are operationalized closer to the theory. She used relational goods to develop a measure of susceptibility to social pressure which incorporates all of an individual's 1) sense of belonging 2) desire to belong and 3) feeling of linked fate with others in the group. She then asked individuals whether they thought others in the group expected them to politically participate in specific ways. She found that people who thought they belonged, wanted to belong, thought their fate was linked with others, and thought political action was expected of members of the group were indeed more likely to participate than other people. The result holds even after taking account of other factors that increase participation. Le's approach gets to the crux of a relational good - do you participate more when you care if you are accepted and think that acceptance calls for certain activities? She finds that the answer is yes for a number of types of participation, with the effect especially pronounced for activities which others can observe. She also finds that recruitment increases participation in highly visible activities. She could, but has not yet, directly assess whether the people who respond

17 One example of Leighley's intermittent (over) interpretation: «Uhlaner's 'relational goods' argument... posits that minority group members will be more likely to participate (i.e. contribute) as their group increases in size» (Leighley, 1991: 128)

18 As she notes, this is contrary to her expectation for Anglos. 
most to recruitment are those who care the most about belonging to the community.

\section{CONCLUSION}

Human beings engage in collective endeavors with each other to produce public goods, even when this behavior puzzles social scientists who believe in human rationality. The puzzle has particularly vexed students of political participation. Many solutions to this paradox have relied on people valuing something in addition to the collective outcome of their actions. If what people additionally value takes the form of ordinary private or public goods, such as getting a souvenir tee-shirt if they turn up at a campaign rally, then traditional analyses suffice. The structure of analysis changes, however, when we recognize that people also value goods that exist only in the interaction between themselves and others, such as shared experiences with a friend at the rally. These relational goods demand a different approach to analysis. They also lead to conclusions which make collective behavior more likely and thus less puzzling. The person who goes to the rally for the tee-shirt would be just as happy if the tee-shirt were delivered to his door without the trouble of attending the event. The person who wants to savor memories of an experience with a friend needs both the experience and the friend.

Research has shown that people are more likely to participate when asked and even more likely when the recruiter is someone they know, thus when direct relational goods may be at stake. Elite actions to mobilize participation also increase activity. Clearly one person can reduce the costs of activity for another, for example by providing information. But why would being the recipient of a request increase the propensity to act? Relational goods provide an answer. Moreover, development of the theoretical implications of relational goods leads to specific expectations about which elite messages could mobilize activity. Elite mobilization is particularly likely to rely on provision of relational goods when group membership is invoked.

The social science literature is filled with studies indicating the importance of group identification for political behavior, including political participation, especially for groups relatively excluded from power, such as women and members of minority racial and ethnic groups. Relational goods help clarify why politicized group identification, such as group consciousness and feelings of linked fate, generally increases participation. But they also suggest why sometimes these have little or no effect. The disparity may arise from where the indirect relational goods associated with the group sit on the con- 
tinuum from relatively anonymous to almost direct. The politicized group identifications may more effectively increase participation when they are undergirded by direct relational goods

We thus circle back to the problematic issue of «identity» as a characteristic of relational goods. The empirical results suggest that indirect relational goods will be most effective in increasing activity when there is more interaction with specific others, that is when they lie closer to the direct end of the continuum or when direct relational goods are at stake. Thus, turnout increases more when Gerber Green Larimer (2008) tell their respondents the voting history of specific named neighbors than when Panagoloulos (2010) promises to publish the names of voters and abstainers. Panagoloulos (2010) finds a larger effect in tiny communities than in a larger town, where neighbors are less likely to face the people who read a list in the newspaper. Further support comes from Le's (2013) finding that the effects of social pressure are stronger for activities more readily observed by other people. For an action to be visible, other people must be around, so a direct relational good is obtainable.

The indirect relational goods appear to operate most powerfully where joined with a direct element as well, that is when they are closer to the identity pole and farther from anonymity. One reason is that anonymity increases the reliance on self-enforcement. With more face-to-face contact, especially for more visible actions, surveillance is possible. People can less readily lie about their behavior; they can be seen to act, or not. Secondly, when people are only distantly and indirectly connected they may perceive group norms very differently; they may even hold contradictory beliefs as to what is required to maintain their «standing» and membership and never be aware of a discrepancy. In a direct relationship, people can correct each other in both regards. The more indirect the relational good the more subjectivity is involved.

These considerations suggest which kinds of groups may be better-suited than others to give rise to indirect relational goods. Groups differ as to how easily members can be identified by others who do not know them personally. Sharing race or gender means that one can be identified by other group members - for compliance with norms, for learning normative behavior, for accepting others- even absent personal acquaintance. Members can also be more readily identified by the majority for out-group treatment. Other groups, such as ones defined by religion or ideology or many ethnicities, are not as identifiable. Perhaps members of such groups wear a visible symbol of their identity, such as distinctive dress (a turban), symbols (a necklace with a cross or a shamrock), buttons («Save the Whales»), to advertise their 
membership. Then fellow members who spot them can believe they will act in accord with the group's norms and extend acceptance. Groups differ also in the intensity with which their members identity, although the amount of that intensity is not exogenous. Nonetheless, given some level, it affects the value of relational goods. Lying to oneself will be costlier the more one is psychologically invested in having a particular identity and accepts the norms which go along with it. ${ }^{19}$ The tough theoretical issue remains of delineating how well-defined or known the «other» needs to be for relational goods to exist. Where there is direct interaction with others the relational goods can be fairly straightforward. Where the interaction is not direct, but only occurs subjectively for the person, what defines the other? What balance of objective and subjective identification is needed for a group to be able to provide relational goods?

Wherever that boundary may lie, relational goods put the connections among human beings back into the study of human behavior.The paradox of political participation arises when we think of people acting only as isolated egoists. Collective action makes more sense for people who also value their connections with each other.Those connections can extend to relationships with people one has never met, but with whom one identifies (whether because of some shared demographic characteristic or for other reasons). Leaders can use relational goods in such settings to mobilize collective action. Relational goods help explain why people join to act together.

\section{BIBLIOGRAPHY}

Aldrich, J. H. (1993): «Rational Choice and Turnout», American Journal of Political Science, 37 (Feb.), pp. 246-278.

Austin, S.D.W.et al. (2012): "The Effect of Racial Group Consciousness on the

Political Participation of African Americans and Black Ethnics in MiamiDade County, Florida», Political Research Quarterly, 65 (Sept.), pp. 629641.

Bardsley, N. (2005): "Interpersonal Interaction and Economic Theory: The Case of Public Goods» in Gui, B. and R. Sugden (eds.) (2005): Economics and Social Interaction: Accounting for Interpersonal Relations, Cambridge, Cambridge University Press. 
Barreto, M. (2007): «Sí Se Puede! Latino Candidates and the Mobilization of Latino Voters», American Political Science Review, 101 (August), pp. 425441.

Barreto, M. et al. (2004): «The Effects of Overlapping Majority-Minority Districts on Latino Turnout», American Political Science Review, 98 (February), pp. 65-75.

- (2005): «Metropolitan Latino Political Behavior: Turnout and Candidate Preference in Los Angeles», Journal of Urban Affairs, 27 (February), pp. 71-91.

BlaIs, A. (2000): To Vote or Not to Vote: The Merits and Limits of Rational Choice Theory, Pittsburgh, Pa., University of Pittsburgh Press.

Bobo, L. and F. D. Gilliam, JR. (1990): «Race, Sociopolitical Participation and Black Empowerment», American Journal of Political Science, 84 (June), pp. 377-393.

Bond, R. et al. (2012): "A 61-Million-Person Experiment in Social Influence and Political Mobilization», Nature, 489, no. 7415 (Sept 13), pp. 295-298.

Bruni, L. (2008): «Back to Aristotle? Happiness, Eudaimonia, and Relational Goods» in Bruni, L. et al. (eds.) (2008): Capabilities and Happiness, Oxford, Oxford University Press.

Bruni, L. and S. Zamagni (L. Zsolnai ed.)(2007): Civil Economy: Efficiency, Equity, Public Happiness, [Serie: Frontiers of Business Ethics, vol. 2], Oxford, Peter Lang.

Burns, N. et al. (2001): The Private Roots of Public Action, Cambridge, Harvard University Press.

Dawson, M. C. (1994): Bebind the Mule: Race and Class in African-American Politics, Princeton, Princeton University Press.

- (2003): Black Visions: The Roots of Contemporary African-American Political Ideologies, Chicago, University of Chicago Press.

DonAt, P. (1986): Introduzione alla sociologia relazionale, Milan, F. Angeli.

- (2011): Relational Sociology: A New Paradigm for the Social Sciences, [Serie: Ontological Explorations], New York, Routledge.

GAY, C. (2001): "The Effect of Black Congressional Representation on Political Participation», American Political Science Review, 95, pp. 589-602.

Gerber, A. S. and D. P. Green (2000): «The Effects of Canvassing, Telephone Calls, and Direct Mail on Voter Turnout: A Field Experiment», American Political Science Review, 94, pp. 653-663.

Gerber, A. S. et al. (2008): «Social Pressure and Voter Turnout: Evidence from a Large-Scale Field Experiment», American Political Science Review, 102, pp. 33-48. 
- (2010): «An Experiment Testing the Relative Effectiveness of Encouraging Voter Participation by Inducing Feelings of Pride or Shame», Political Behavior, 32, pp. 409-422.

Green, D. P. and A. S. Gerber (2008): Get Out the Vote: How to Increase Voter Turnout, $2^{\text {nd }}$ ed., Washington, D.C., Brookings Institution Press.

Green, D. P. et al. (2013): «Field Experiments and the Study of Voter Turnout», Journal of Elections, Public Opinion \& Parties, 23, pp. 27-48.

GuI, B. (1987): «Elements pour une definition d'economie communautaire», Notes et Documents, 19-20, pp. 32-42.

- (2000): «Beyond Transactions: On the Interpersonal Dimension of Economic Reality», Annals of Public and Cooperative Economics, Special Issue on «Economics and Interpersonal Relations» (ed. GuI, B), 71, pp. 139169.

- (2005): «From Transactions to Encounters: The Joint Generation of Relational Goods and Conventional Values» in GuI, B. and R. Sugden (eds.) (2005): Economics and Social Interaction:Accounting for Interpersonal Relations, Cambridge, Cambridge University Press.

JaCKson, B. O. (1987): «The Effects of Racial Group Consciousness on Political Mobilization in American Cities», Western Political Quarterly, 40, pp. 631646.

LE, D. (2013): Under Pressure? Effects of Social Pressure on Political Participation in a Vietnamese Community in California. Ph.D. diss., Univ. of California, Irvine.

Leighley, J. E. and A. Vedlitz (1999): «Race, Ethnicity, and Political Participation: Competing Models and Contrasting Explanations»,Journal of Politics, 61, pp. 1092-1114.

LeIghley, J. E. (2001): Strength in Numbers? The Political Mobilization of Racial and Ethnic Minorities, Princeton, Princeton University Press.

LIEN, P. (1994): «Ethnicity and Political Participation: A Comparison Between Asian and Mexican Americans», Political Behavior, 16, pp. 237-264.

McClain P. D. and J. SteWART (2006): Can We All Get Along? Racial and Ethnic Minorities in American Politics, Boulder, Colorado, Westview.

McClaIn, P. D. et al. (2009): «Group Membership, Group Identity, and Group Consciousness: Measures of Racial Identity in American Politics?», Annual Review of Political Science, 12, pp. 471-485.

Miller, A. H. et al. (1981): «Group Consciousness and Political Participation», American Journal of Political Science, 25, pp. 494-511.

Nussbaum, M. C. (1986): The Fragility of Goodness: Luck and Ethics in Greek Tragedy and Philosophy, Cambridge, Cambridge University Press. 
Panagopoulos, C. (2010): «Affect, Social Pressure and Prosocial Motivation: Field Experimental Evidence of the Mobilizing Effects of Pride, Shame and Publicizing Voting Behavior», Political Behavior, 32, pp. 369-386.

Panagopoulos, C. et al. (2013): «Social Pressure, Descriptive Norms, and Voter Mobilization», Political Behavior, [link.springer.com/article/10.1007/ s11109-013-9234-4/fulltext.html] [DOI 10.1007/s11109-013-9234-4].

ReIngold, B. and J. Harrell (2010): «The Impact of Descriptive Representation on Women's Political Engagement: Does Party Matter?», Political Research Quarterly, 63, pp. 280-294.

Rocha, R. R. et al. (2010): «Race and Turnout: Does Descriptive Representation in State Legislatures Increase Minority Voting?», Political Research Quarterly, 63, pp. 890-907.

SANChez, G. R. (2006): «The Role of Group Consciousness in Political Participation Among Latinos in the United States», American Politics Research, 34 , pp. $427-450$.

Sanchez, G. R. and N. Masuoka (2010): «Brown-Utility Heuristic? The Presence and Contributing Factors of Latino Linked Fate», Hispanic Journal of Behavioral Sciences, 32, pp. 519-531.

Shingles, R. D. (1981): «Black Consciousness and Political Participation: The Missing Link», American Political Science Review, 75, pp. 76-91.

SINCLAIR, B. et al. (2012): «Detecting Spillover Effects: Design and Analysis of Multilevel Experiments», American Journal of Political Science, 56, pp. 1055-1069.

Stokes,A. K. (2003): «Latino Group Consciousness and Political Participation», American Politics Research, 31, pp. 361-378.

Sugden, R. (1984): «Reciprocity: The Supply of Public Goods Through Voluntary Contributions» Economic Journal, 94, pp. 772-787.

- (2002): «Beyond Sympathy and Empathy: Adam Smith's Concept of Fellow-Feeling», Economics and Pbilosophy, 18, pp. 63-87.

- (2005): «Fellow-Feeling» in GuI, B. and R. SugdeN (eds.) (2005): Economics and Social Interaction: Accounting for Interpersonal Relations, Cambridge, Cambridge University Press.

TAJFEL, H. et al. (1971): «Social Categorization and Intergroup Behavior», European Journal of Social Psychology, 1, pp. 149-178.

TAJFEL, H. (1982): «Social Psychology of Intergroup Relations», Annual Review of Psychology, 33, pp. 1-39.

Tate, K. (1991): «Black Political Participation in the 1984 and 1988 Presidential Elections», American Political Science Review, 85, pp. 1159-1176. 
- (2003): Black Faces in the Mirror: African Americans and their Representatives in the U.S. Congress, Princeton, N. J., Princeton University Press.

Turner, J. C. (1975): «Social Comparison and Social Identity: Some Prospects for Intergroup Behavior», European Journal of Social Psychology, 5, pp. $1-34$.

- (1982): «Toward a Cognitive Redefinition of the Social Group» in TAJFeL, H. (ed.) (1982): Social Identity and Intergroup Relations, New York, Cambridge University Press.

Uhlaner, C. J. (1986): «Political Participation, Rational Actors, and Rationality: A New Approach», Political Psychology, 7, pp. 551-573.

- (1989a): «Relational Goods and Participation», Public Choice, 62, pp. 253285.

- (1989b): «Rational Turnout: The Neglected Role of Groups», American Journal of Political Science, 33, pp. 390-422.

- (2002): «The Impact of Perceived Representation on Latino Political Participation", Research Monograph 02-06, Center for the Study of Democracy, University of California, Irvine.

Uhlaner, C. J. et al. (1989): «Political Participation of Ethnic Minorities in the 1980s», Political Behavior, 11, pp. 195-231.

Uhlaner, C. J. et al. (2013): «Descriptive Representation and Voter Turnout in the U.S.: Effects of the Intersection of Gender, Race and Ethnicity», manuscript.

Verba, S. and N. Nie (1972): Participation in America: Political Democracy and Social Equality, New York, Harper and Row.

Verba, S. et al. (1995): Voice and Equality: Civic Voluntarism in American Politics, Cambridge, Mass., Harvard University Press. 